\title{
The Study of Structural, Impedance and Energy Storage Behavior of Plasticized PVA:MC Based Proton Conducting Polymer Blend Electrolytes
}

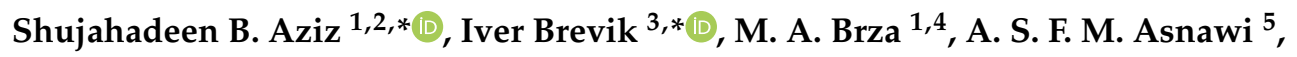 \\ Elham M. A. Dannoun ${ }^{6}$, Y. M. Yusof ${ }^{5}$, Rebar T. Abdulwahid ${ }^{1,7}{ }^{1 D}$, M. H. Hamsan ${ }^{8}$, \\ Muaffaq M. Nofal ${ }^{9}$ (D) and M. F. Z. Kadir ${ }^{10}$ \\ 1 Hameed majid Advanced Polymeric Materials Research Lab., Physics, College of Science, \\ University of Sulaimani, Qlyasan Street, Kurdistan Regional Government-Iraq, Sulaimani 46001, Iraq; \\ mohamad.brza@gmail.com (M.A.B.); rebar.abdulwahid@univsul.edu.iq (R.T.A.) \\ 2 Department of Civil engineering, College of Engineering, Komar University of Science and Technology, \\ Kurdistan Regional Government, Sulaimani 46001, Iraq \\ 3 Department of Energy and Process Engineering, Norwegian University of Science and Technology, \\ N-7491 Trondheim, Norway \\ 4 Department of Manufacturing and Materials Engineering, Faculty of Engineering, \\ International Islamic University of Malaysia, Kuala Lumpur 53100, Malaysia \\ 5 Chemical Engineering Section, Universiti Kuala Lumpur, Malaysian Institute of Chemical \& Bioengineering \\ Technology (UniKL MICET), Alor Gajah 78000, Malacca, Malaysia; \\ asyafiq.asnawi@s.unikl.edu.my (A.S.F.M.A.); yuhanees@unikl.edu.my (Y.M.Y.) \\ 6 Associate Director of General Science Department, Woman Campus, Prince Sultan University, \\ P. O. Box 66833, Riyadh 11586, Saudi Arabia; elhamdannoun1977@gmail.com \\ 7 Department of Physics, College of Education, University of Sulaimani, Old Campus, \\ Kurdistan Regional Government, Sulaimani 46001, Iraq \\ 8 Institute for Advanced Studies, University of Malaya, Kuala Lumpur 50603, Malaysia; \\ hafizhamsan93@gmail.com \\ 9 Department of Mathematics and General Sciences, Prince Sultan University, P. O. Box 66833, \\ Riyadh 11586, Saudi Arabia; muaffaqnofal@gmail.com \\ 10 Centre for Foundation Studies in Science, University of Malaya, Kuala Lumpur 50603, Malaysia; \\ mfzkadir@um.edu.my \\ * Correspondence: shujahadeenaziz@gmail.com (S.B.A.); iver.h.brevik@ntnu.no (I.B.)
}

Received: 18 October 2020; Accepted: 5 November 2020; Published: 7 November 2020

\begin{abstract}
In this study, structural characterization, electrical properties and energy storage performance of plasticized polymer electrolytes based on polyvinyl alcohol/methylcellulose/ammonium thiocyanate (PVA/MC-NH${ }_{4} \mathrm{SCN}$ ) were carried out. An X-ray diffraction (XRD) study displayed that the plasticized electrolyte system with the uppermost value of direct current (DC) ionic conductivity was the most amorphous system. The electrolyte in the present work realized an ionic conductivity of $2.903 \times 10^{-3} \mathrm{Scm}^{-1}$ at room temperature. The main charge carrier in the electrolyte was found to be the ions with the ionic transference number $\left(t_{i o n}\right)$ of 0.912 , compared to only 0.088 for the electronic transference number $\left(t_{\text {elec }}\right)$. The electrochemical stability potential window of the electrolyte is $2.1 \mathrm{~V}$. The specific capacitance was found to reduce from $102.88 \mathrm{~F} / \mathrm{g}$ to $28.58 \mathrm{~F} / \mathrm{g}$ as the scan rate increased in cyclic voltammetry (CV) analysis. The fabricated electrochemical double layer capacitor (EDLC) was stable up to 200 cycles with high efficiency. The specific capacitance obtained for the EDLC by using charge-discharge analysis was $132.7 \mathrm{~F} / \mathrm{g}$ at the first cycle, which is slightly higher compared to the CV plot. The equivalent series resistance (ESR) increased from 58 to $171 \Omega$ throughout the cycles, which indicates a good electrolyte/electrode contact. Ions in the electrolyte were considered to have almost the same amount of energy during the conduction process as the energy density is approximately at $14.0 \mathrm{Wh} / \mathrm{kg}$ throughout the 200 cycles. The power density is stabilized at the range of 1444.3 to $467.6 \mathrm{~W} / \mathrm{kg}$ as the EDLC completed the cycles.
\end{abstract}


Keywords: polymer blends; XRD and impedance study; TNM and LSV; CV; energy storage EDLC device

\section{Introduction}

The first solid polymer electrolyte (SPE) was made for the application in lithium batteries in 1979 and it is now one of the most important elements for applications to electrochemical devices [1]. Proton batteries and electrochemical double layer capacitors (EDLCs) are among the applications that are using SPEs and have been internationally recognized as an option for conventional batteries. While liquid electrolyte shows a good performance in a few energy devices, it can be easily evaporated and also damage the device's internal elements due to corrosive and leakage problems [2-4]. Researchers therefore find that SPEs are the best candidate for replacing the liquid electrolytes considering their protection, long shelf life and also their easy manufacturing process [5]. Moreover, polymers used for polymer electrolyte preparation should have functional groups such as $\mathrm{OH}, \mathrm{C}=\mathrm{O}$ or $\mathrm{NH}_{2}$ on their backbone chains [6-9]. Besides, researchers find that EDLC has higher endurance and power density compared to other supercapacitors [10-12]. EDLC is produced through a simple and cost-effective fabrication process, mainly employing activated carbon, because of its good chemical stability and high electronic conductivity as well as its larger surface area compared to other fabrication materials [13-15]. Moreover, the energy storage of EDLC is manifested through a non-Faradaic mechanism because the ions develop a double layer by the interfacial area [16]. This explains that there is no electron transfer between the electrode surfaces but only charges will accumulate.

Natural polymers are broadly used in the preparation of polymer electrolytes due to their biodegradable properties that meet environmental and global energy requirements. Poly(vinyl alcohol) (PVA) and methylcellulose (MC) are examples of natural polymers that are widely researched in applications regarding electrochemical devices [17-22]. PVA is a non-toxic polymer that, when enriched with polar oxygen atoms from the vinyl alcohol groups, helps to produce complex salt cations, hence forming excellent polymer electrolyte complexes [23,24]. It has been shown to exhibit good characteristics such as high dielectric power, high chemical stability and good storage capacity [25]. It was found in the literature that PVA has shown good results as a host polymer both in terms of conductivity and electrochemical stability [26-28]. In addition, MC-based polymer electrolytes have recently been reported to have a high potential in the fabrication of EDLC [29]. MC is also stated to have good film forming characteristics, be biocompatible and low-cost as well as having good mechanical and electrical characteristics compared to other green polymers [30,31]. It is proposed that MC improves ionic conductivity and is commonly used in many different industries, including mineral processing, textile and medical applications [32]. Instead of using a single polymer to produce SPEs, the blending of two or more different polymers can improve mechanical strength, thermal stability and the availability of ion hopping sites [33,34].

Furthermore, salt addition has been introduced to the electrolyte to enhance its conductivity, which is a key parameter for the performance of the electrochemical devices. Although lithium-based salts show an overall good performance, their non-biodegradable characteristics may cause environmental pollution [35]. $\mathrm{H}^{+}, \mathrm{Mg}^{2+}$, and $\mathrm{NH}^{4+}$ are therefore alternatives to $\mathrm{Li}^{+}$as cation providers in SPEs [2,36]. Hemalatha et al. [37] reported that the lattice energy of $\mathrm{NH}_{4} \mathrm{SCN}(605 \mathrm{~kJ} / \mathrm{mol})$ can cause the cation and anion to be easily dissociated during dissolution in a solvent. This phenomenon has led to an increase in ammonium ions in the polymer matrix provided by the $\mathrm{NH}_{4} \mathrm{SCN}$ [38]. The incorporation of $\mathrm{NH}_{4} \mathrm{SCN}$ salt reported an increment of room temperature conductivity for the carboxymethyl cellulose (CMC)-based polymer electrolyte up to $6.48 \times 10^{-5} \mathrm{~S} / \mathrm{cm}$ [39]. Besides, Premalatha et al. [40] have also reported that the blend of polyvinyl alcohol (PVA) and polyacrylic nitrile (PAN) films have achieved the maximum conductivity of $3.25 \times 10^{-3} \mathrm{~S} / \mathrm{cm}$ at room temperature with the addition of $\mathrm{NH}_{4} \mathrm{SCN}$ salt. The future challenge to achieve environmental friendly energy storage devices 
and minimize pollution have attracted the attention of many research groups. In fact, it is not an easy task to obtain the balance between good device performances, cost reduction and the use of eco-friendly materials. In this work we focused on the preparation and study of eco-friendly polymer electrolytes based on biodegradable polymers such as PVA and MC in an attempt to reduce electronic wastes. This work is a part of large effort and numerous researches carried out across the globe by scientists toward commercializing the biodegradable polymer electrolyte in energy devices such as batteries, supercapacitors and solar cells. In addition, from the economical view point, these types of biodegradable polymer electrolytes can play a main role in reducing the cost of electronic devices, both in terms of used raw materials and fabrication processes. The current research investigating the possibility and suitability of using biodegradable polymers in energy devices, which conceptually is a good realistic step toward the development and commercialization of eco-friendly energy devices. In the present work, the highest conducting electrolyte (PVA:MC blend with $40 \mathrm{wt} . \% \mathrm{NH}_{4} \mathrm{SCN}$ and $48 \mathrm{wt}$.\% Glycerol) have been studied using various experimental techniques and have been fabricated into the EDLC.

\section{Experimental}

\subsection{Material and Preparation of Blend SPE Films}

MC and PVA with the average molecular weight of 35,000 g/mol, obtained from Sigma Aldrich were used as raw materials in a powder form. $\mathrm{NH}_{4} \mathrm{SCN}$ salt has been used as an $\mathrm{H}^{+}$ion provider for the polymer blend electrolyte. Raw materials were used to prepare PVA:MC: $\mathrm{NH}_{4} \mathrm{SCN}$ polymer blend electrolyte films through solution casting technique. The PVA:MC blends in 90:10 and 80:20 in weight percent were prepared. For this work, MC (10 and $20 \mathrm{wt} . \%)$ was dissolved separately in distilled water at an ambient temperature for $5 \mathrm{~h}$. Concurrently, PVA (90 and $80 \mathrm{wt} . \%$ ) were dissolved separately in distilled water $(20 \mathrm{~mL})$ at $80{ }^{\circ} \mathrm{C}$. The PVA solution was allowed to cool down to room temperature. Then PVA and MC solutions were mixed under magnetic stirrer with continuous stirring. Consequently, for the PVA:MC (80:20) blend, $40 \mathrm{wt} . \%$ of $\mathrm{NH}_{4} \mathrm{SCN}$ salt dopant was added and stirred until a clear solution was obtained. Then, $14,28,42 \mathrm{wt} . \%$ of glycerol plasticizer (GCP) was added to the PVA:MC: $\mathrm{NH}_{4} \mathrm{SCN}$ electrolyte in order to prepare a plasticized polymer electrolyte and then the plasticized solutions were coded as PMNG-1, PMNG-2, and PMNG-3, respectively. Lastly, the solution mixtures were poured into different clean Petri dishes and left to evaporate gradually at an ambient temperature for several days.

\subsection{EIS Measurements}

Electrical impedance spectroscopy (EIS) is employed to analyze conductivity and other characteristics by measuring the impedance of electrolytes. At a frequency range of $50 \mathrm{~Hz}$ to $1000 \mathrm{kHz}$, HIOKI 3532-50 LCR HiTESTER is used for the measurement. Prior to this test, two stainless steel electrodes were used to place the selected electrolyte in between them before the measurement is taken. By using the following equation, room temperature conductivity can be calculated for each electrolyte $[14,15]$.

$$
\sigma_{d c}=\left(\frac{1}{R_{b}}\right) \times\left(\frac{t}{A}\right)
$$

where $t$ and $A$ represent the thickness of the electrolyte and the electrode-electrolyte contact area, respectively, while, $R_{b}$ is the bulk resistance which is taken from the spike-real axis interception.

\subsection{LSV and TNM Studies}

The decomposition voltage of the electrolytes exhibits their stability electrochemically, which can be evaluated through a linear sweep voltammetry (LSV) study. The LSV recording was carried out by using Digi-IVY DY 2300 potentiostat at scan rate of $10 \mathrm{mV} / \mathrm{s}$. Besides, transference number measurement (TNM) was computed through a V\&A Instrument DP3003 at room temperature with a $0.2 \mathrm{~V}$ working 
voltage and a digital DC power supply. The electronic $\left(t_{\text {elec }}\right)$ and ionic $\left(t_{\text {ion }}\right)$ transference numbers were analyzed from the cell polarization versus time. The transference numbers for both ionic and electronic are calculated using the following equations $[14,15]$ :

$$
\begin{gathered}
t_{\text {ion }}=\frac{I_{i}-I_{S S}}{I_{i}} \\
t_{\text {elec }}=\frac{I_{S S}}{I_{i}}
\end{gathered}
$$

where $I_{i}$ and $I_{s s}$ are the initial current and steady state currents, respectively.

\subsection{EDLC Preparation}

For the EDLC preparation in this study, the electrode was mainly fabricated using three main materials, which are carbon black, activated carbon and polyvinylidene fluoride (PVdF). Details of the electrode preparation were reported in our previous work [41]. Once the electrode was successfully prepared, the arrangement of the EDLC in a coin cell was (electrode | highest conducting electrolyte | electrode) as schematically illustrated in Scheme 1, and it is ready to be analyzed.

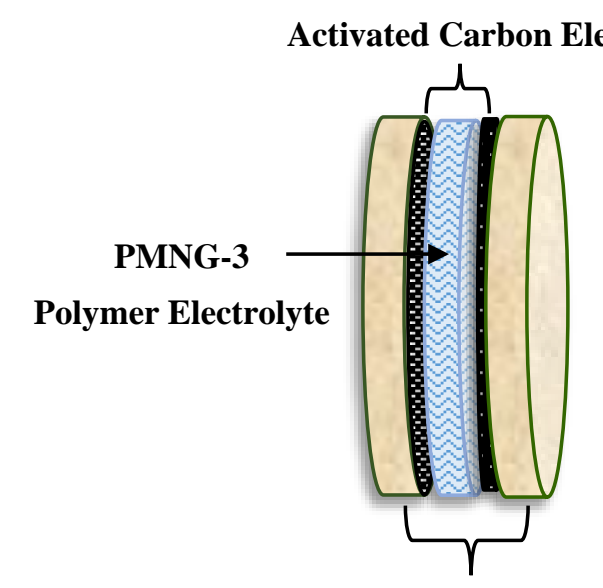

Aluminum Foils

Scheme 1. Schematic arrangement of the fabricated EDLC.

The performance of EDLC was first tested using a cyclic voltammetry (CV) analysis, where Digi-IVY DY2300 Potentiostat was occupied with a voltage range 0.0 to $0.9 \mathrm{~V}$ and sweep rates range of 10 to $100 \mathrm{mV} / \mathrm{s}$. The specific capacitance $\left(C_{s}\right)$ from $\mathrm{CV}$ analysis can be calculated by using the equation below [21,22]:

$$
C_{c v}=\int_{V_{l}}^{V_{2}} \frac{I(V) d V}{2 m v\left(V_{2}-V_{1}\right)}
$$

where $I(V) d V$ represents the area of $C V$ curves, $m$ is the active materials mass and $v$ is the scan rate used during the measurements. $V_{1}$ and $V_{2}$ are 0.0 and $0.9 \mathrm{~V}$, respectively.

Another important analysis of the prepared EDLC is the charge-discharge profiles, which was measured at a current density of $0.5 \mathrm{~mA} / \mathrm{cm}^{2}$ by using a Neware battery cycler. By using the Equations (5) and (6), $C_{S}$ values from charge-discharge profiles as well as the equivalent series resistance (ESR) can be determined for 200 cycles [20-22].

$$
\begin{aligned}
C_{s} & =\frac{i}{m s} \\
E S R & =\frac{V_{d r o p}}{i}
\end{aligned}
$$


where $I$ and $s$ represent the applied current and the discharge slope, respectively while $V_{\text {drop }}$ is the voltage drop.

\section{Results and Discussion}

\subsection{Structural Study}

Figure 1 shows the XRD patterns for the pure PVA, PVA:MC blends, and plasticized electrolyte films. It is documented that MC polymer possesses a unique peak at $2 \theta$ between $19^{\circ}$ and $21^{\circ}$, arising from the inter-molecular hydrogen bonding coupled with a short distance order in the MC chains [42-45]. Early studies showed that the XRD spectrum of pure PVA possesses various crystalline peaks at $2 \theta=20^{\circ}, 23.43^{\circ}$, and $41.15^{\circ}$ which are attributed to (101), (200), and (111) planes, respectively [46,47]. The emerged intense peak at $2 \theta=18.6^{\circ}$ in the XRD spectrum of pure PVA showed that the PVA has a semicrystalline structure [48]. The $\mathrm{OH}$ group existence along the PVA main chain is sufficient to offer strong intra-molecular and inter-molecular hydrogen bonding in PVA. This study has shown that as the concentration of MC increased from 10 to $20 \mathrm{wt} . \%$, the intensity of the crystalline peaks of PVA decreased and the peaks underwent broadening (see Figure $1 b, c)$. This is caused by disruption of hydrogen bonding due to the dominance of the amorphous phase in the blend system. Thus, polymer blending might be considered as an effective methodology to decrease the PVA crystalline segment. To determine the degree of crystallinity $\left(X_{c}\right)$, it is essential to deconvolute the XRD spectra of the samples to find the area of the amorphous and crystalline peaks [49]. The $X_{c}$ was calculated using Equation (7) [50].

$$
\mathrm{Xc}=\frac{A_{\mathrm{C}}}{A_{T}} \times 100 \%
$$

where $A_{C}$ and $A_{T}$ are the area of crystalline peaks and total area of amorphous and crystalline peaks, respectively. It is noteworthy to observe that the $X_{c}$ is decreased upon further increasing the MC content (see Table 1). The deconvoluted XRD spectra of the plasticized PVA:MC electrolyte is shown in Figure $1 \mathrm{~d}$,e. It is fascinating to observe that the intensity of the XRD peaks is considerably decreased upon an increasing in GCP. A previous study reported that salt inclusion into the polymer blends markedly reduced the $X c[20,21,51]$. On the basis of previous research, salt can destroy the hydrogen bonding amongst the polymer chains because of electrostatic reactions created among the salt cations and polymer functional groups [52]. The amorphous structure increment might be associated with the crystalline phase disruption in the polymer [53]. Compared to the pure blend systems, the degree of crystallinity in the plasticized systems is very significantly diminished (see Table 1). Using plasticizers are famous approaches to raise the free ions number and decrease the $X_{c}$ [54].

Table 1. The $X_{c}$ using deconvoluted XRD examination.

\begin{tabular}{cc}
\hline Electrolyte & $\begin{array}{c}\text { Degree of Crystallinity } \\
(\mathbf{\%})\end{array}$ \\
\hline Pure PVA & 41.68 \\
PVA:MC (90:10) & 38.52 \\
PVA:MC (80:20) & 28.57 \\
PMNG-1 & 6.88 \\
PMNG-3 & 1.98 \\
\hline
\end{tabular}



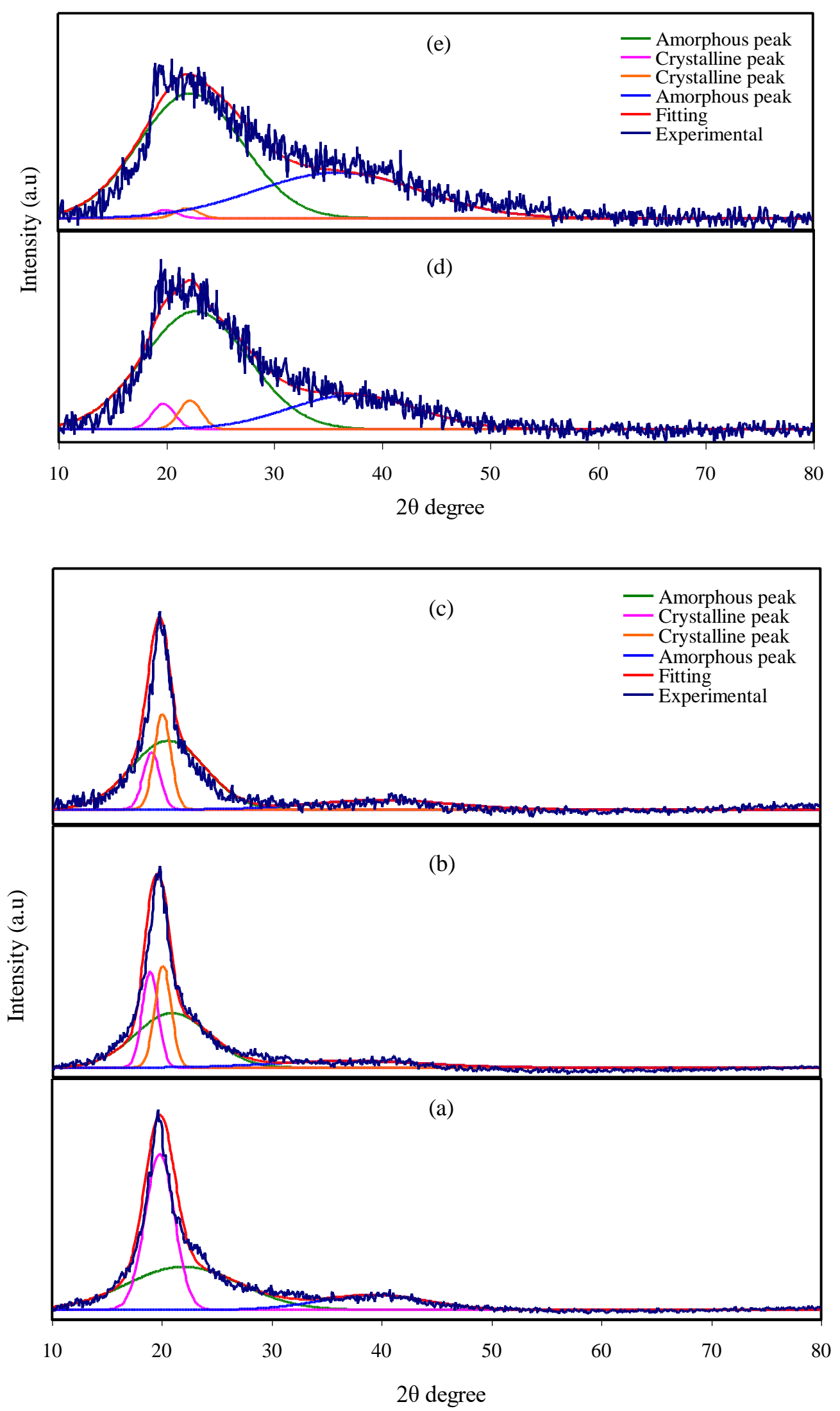

Figure 1. XRD spectra for (a) pure PVA, (b) 90 wt.\% PVA:10 wt.\% MC, (c) 80 wt.\% PVA:20 wt.\% MC, (d) PMNG-1, and (e) PMNG-3 electrolyte films. 


\subsection{Impedance Analysis}

Impedance spectroscopy is an effective method to investigate the electrical properties as well as to explore the conductive properties of polymeric materials that will be applied in electrochemical devices [6,55]. Over the years, the focus has been given to the ionic conducting materials because of the wide application range in solid electrochemical device fields [56]. The impedance plots at room temperature for the PVA:MC: $\mathrm{NH}_{4} \mathrm{SCN}$ :Gly electrolyte films are displayed in Figure 2a-c, where $\left(Z_{r}\right)$ is the real part and $\left(Z_{i}\right)$ is the imaginary part of the complex impedance $\left(Z^{*}\right)$.
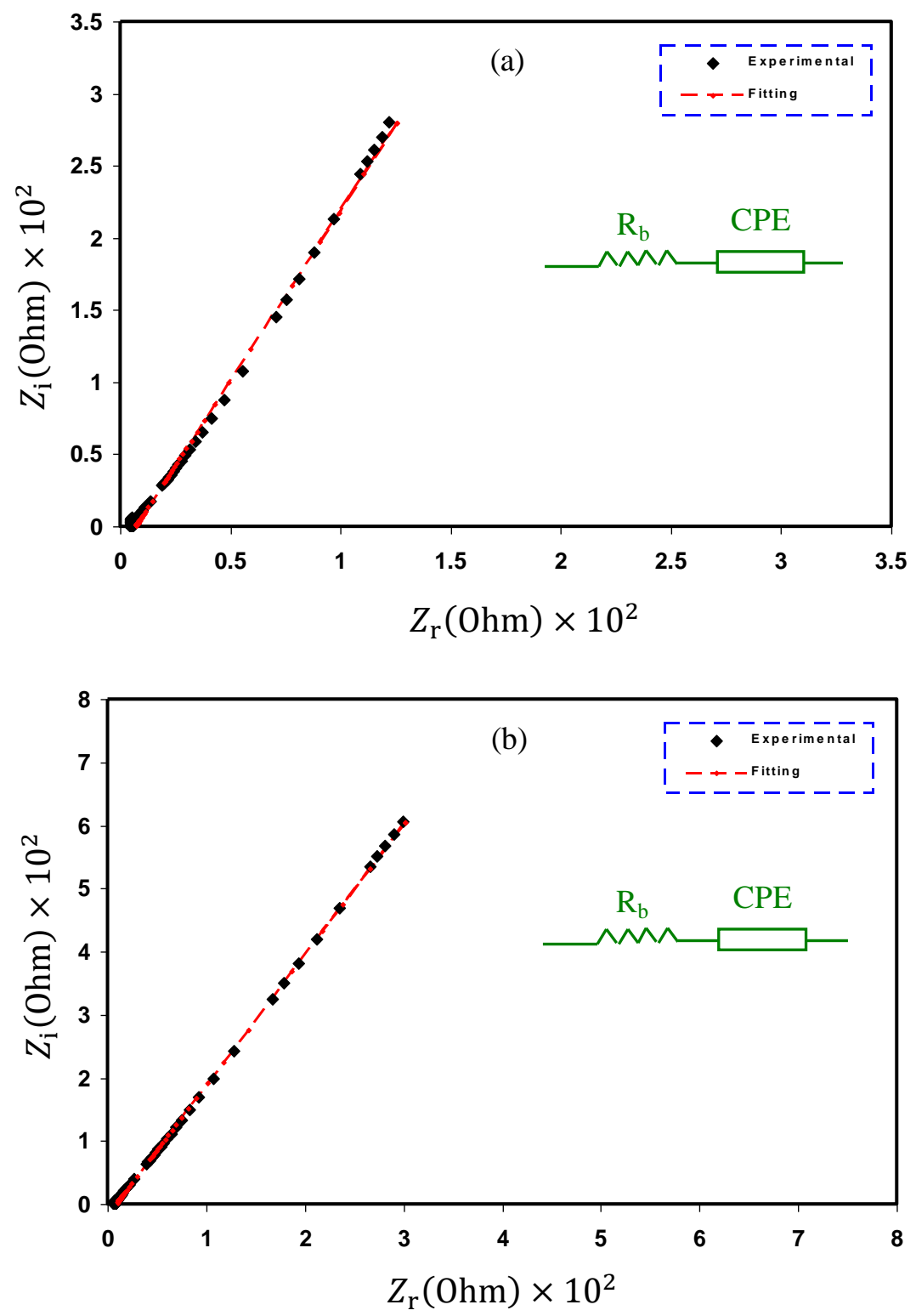

Figure 2. Cont. 


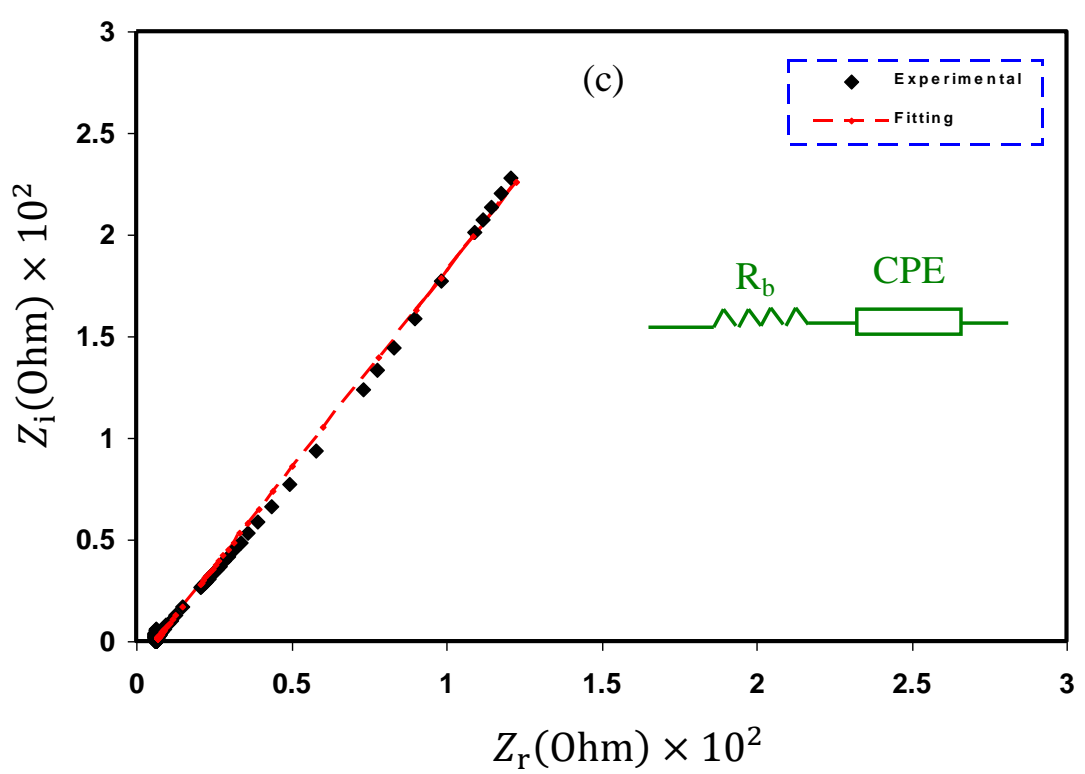

Figure 2. EIS plots for (a) PMNG-1, (b) PMNG-2, and (c) PMNG-3 electrolyte films.

Based on Figure 2, a less than $90^{\circ}$ inclined spike is detected at low frequency, which verifies the capacitive aspect in the electrolyte [57]. This situation illuminates the electrode polarization effect within the electrolytes $[58,59]$. The development of the electric double layer and free charge buildup are the cause for this phenomenon to happen at the electrolyte and electrode surface interface [60]. It is noticeable in Figure 2a,b that with rising GCP content the bulk resistance $\left(R_{b}\right)$ increased. This might be due to the association of cations and anions in the salt, which hinders ion transportation and segmental mobility, and thus causes the decrement in conductivity [61]. It is seen in Figure $2 c$ that the $R_{b}$ value is decreased as the GCP increases to $42 \mathrm{wt} . \%$ because of the charge carrier mobility increment, resulting in the increment in the conductivity [62].

The values of $R_{b}$ are measured at the point where the semicircle intercepts the real axis $\left(Z_{r}\right)$. Equation (1) is employed to measure the films DC conductivity on the basis of $R_{b}$ values and the films dimensions. Table 2 lists the DC conductivity for the plasticized system. The highest conductivity of the plasticized electrolyte system is a promise for application in EDLC. According to Kadir et al. [29], the addition of $30 \mathrm{wt} . \%$ GCP in MC: $\mathrm{NH}_{4} \mathrm{Br}$ electrolyte system showed the ionic conductivity of $(1.67 \pm 0.04) \times 10^{-3} \mathrm{Scm}^{-1}$. The conductivity value achieved by the electrolyte in this work is comparable to the literature that reported high conductivity such as $3.73 \times 10^{-3} \mathrm{Scm}^{-1}$ for lignin-based gel polymer electrolytes [35], $3.04 \times 10^{-4} \mathrm{Scm}^{-1}$ for corn starch/chitosan/ammonium iodide-based electrolytes [36] and $1.17 \times 10^{-3} \mathrm{Scm}^{-1}$ for PVA/amino acid proline/ $\mathrm{NH}_{4} \mathrm{SCN}$-based electrolytes [37].

Table 2. DC conductivity for PVA:MC: $\mathrm{NH}_{4} \mathrm{SCN}$ :Gly systems at room temperature.

\begin{tabular}{ccc}
\hline Designation & $\mathbf{R}_{\mathbf{b}}(\mathbf{O h m})$ & Conductivity $\left(\mathbf{S ~ c m}^{-\mathbf{1}}\right)$ \\
\hline PMNG-1 & 7 & $1.92 \times 10^{-3}$ \\
PMNG-2 & 8.5 & $1.58 \times 10^{-3}$ \\
PMNG-3 & 6 & $2.24 \times 10^{-3}$ \\
\hline
\end{tabular}

The low frequency region would be presented by a constant phase element (CPE), which is related to the formed double-layer capacitance between the electrode and the blend electrolyte. The CPE is usually used in an electric equivalent circuit (EEC) rather than an ideal capacitor in real systems. This is because the real SPE behavior is unlike that of an ideal capacitor engaged in a pure semicircular pattern [63]. The spike character of the plasticized electrolytes indicates that just the resistive part of the 
polymer dominates [64]. In this case, the values of $Z r$ and $Z i$ associated with the EEC can be expressed as [22]:

$$
\begin{gathered}
Z_{r}=R_{b}+\frac{A 1}{C \omega^{p}} \\
Z_{i}=\frac{A 2}{C \omega^{p}}
\end{gathered}
$$

where

$$
A 1=\cos \left(\frac{\pi p}{2}\right) \text { and } A 2=\sin \left(\frac{\pi p}{2}\right)
$$

where $C$ is the $\mathrm{CPE}$ capacitance, $\omega$ refers to the angular frequency and $P$ is associated with the vertical axis deviation of the impedance plots. The EEC fitting parameters are shown in Table 3.

Table 3. The EEC fitting parameters for PVA:MC: $\mathrm{NH}_{4} \mathrm{SCN}$ :Gly systems at room temperature.

\begin{tabular}{ccc}
\hline Sample & $\mathbf{K}\left(\boldsymbol{F}^{-\mathbf{1}}\right)$ & $\mathbf{C}(\boldsymbol{F})$ \\
\hline PMNG-1 & $2.2 \times 10^{4}$ & $4.55 \times 10^{-5}$ \\
PMNG-2 & $4.05 \times 10^{4}$ & $2.47 \times 10^{-5}$ \\
PMNG-3 & $1.40 \times 10^{4}$ & $7.14 \times 10^{-5}$ \\
\hline
\end{tabular}

Where $\mathrm{K}$ is the reciprocal value of specific capacitance and it measured in $\mathrm{F}^{-1}$.

\subsection{TNM Analysis}

The transference number measurement (TNM) analysis exhibits which charge carrier species is dominant within the electrolytes. When the ionic transference number $\left(t_{i o n}\right)$ is near to unity, the system is confirmed to be dominated by ions [65]. The current plot against time for the PMNG-3 system is presented in Figure 3.

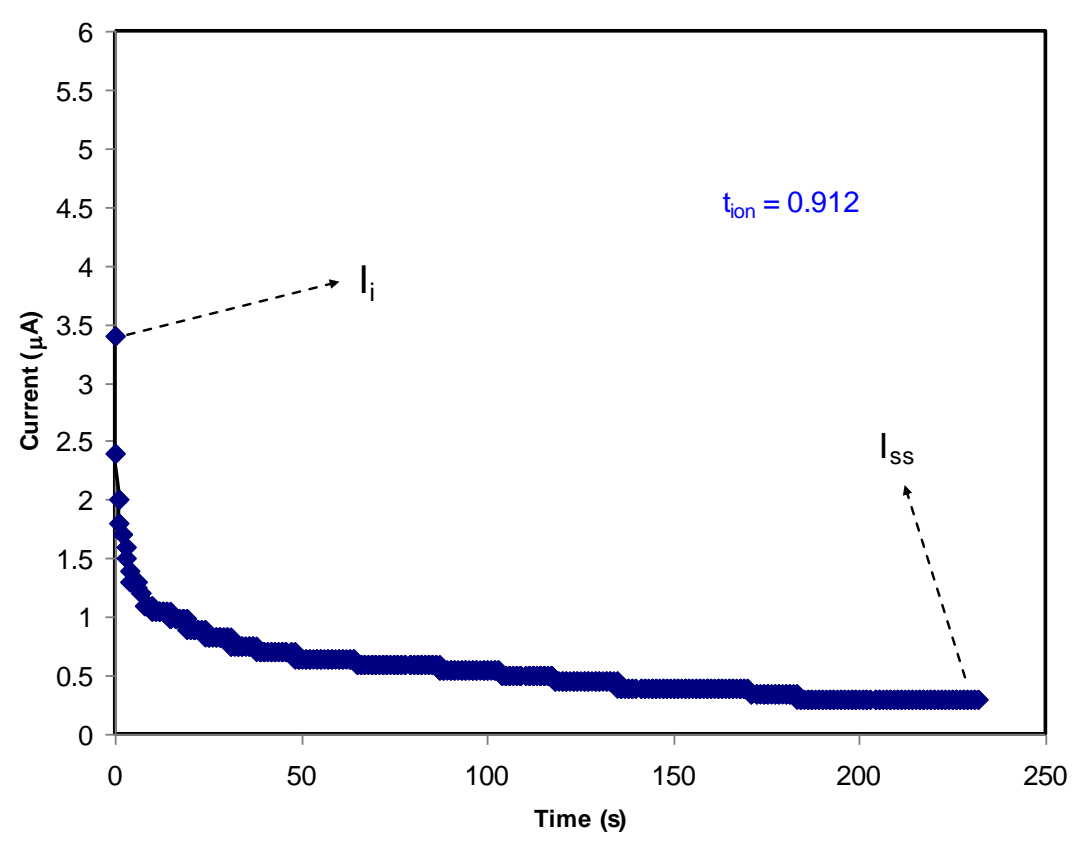

Figure 3. Current versus time for the PMNG-3 system.

Based on Figure 3, the initial current is noticed to decrease as the time increases due to the depletion of ionic species, and a balanced mobile ion diffusion process will result in a steady state of current $[66,67]$. The ions are blocked by the stainless steel electrodes during the polarization process, while only electrons can flow through [68]. The electrolyte shows a $t_{\text {ion }}$ value of 0.912 , whereas the $t_{\text {elec }}$ is 0.088 and this verifies that ions are the major carrier species in the PMNG-3 system. The result obtained for the PMNG-3 electrolyte is recommended for the good performance in the electrochemical 
devices application, particularly EDLC. This is due to the good DC conductivity value, which is recorded for this system. In addition to its sufficient electrochemical stability, which will be discussed in a later section. The glycerolized chitosan- $\mathrm{NH}_{4} \mathrm{Br}$ system also reported a comparable result [69].

\subsection{LSV Study}

The linear sweep voltammetry (LSV) is used to examine the voltage that an electrolyte can operate without breakdown at room temperature [70]. Figure 4 illustrates the LSV plot of the PMNG-3 electrolyte at $10 \mathrm{mV} / \mathrm{s}$. No current flow is observed in the electrolyte when the voltage is below $2.1 \mathrm{~V}$, which explains that the electrochemical reaction does not occur within the electrolyte [71]. Therefore, the decomposition of the PMNG-3 system is observed to start at a voltage of $2.1 \mathrm{~V}$, which is suitable enough to be used for the fabrication of EDLC that normally works at $1.0 \mathrm{~V}$ [72].

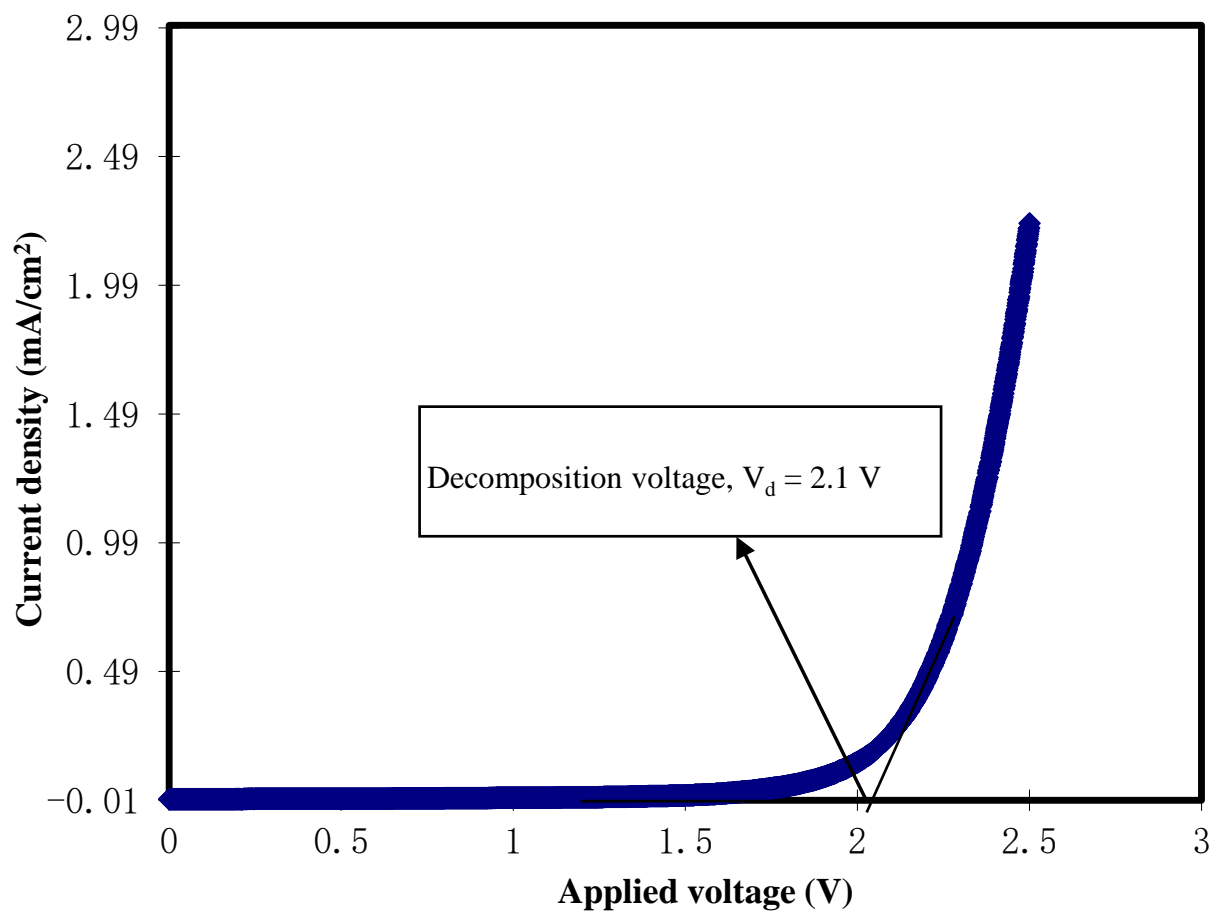

Figure 4. Linear sweep voltammetry (LSV) curve for the PMNG-3 system.

\section{5. $C V$ and EDLC Characterization}

The CV analysis is conducted to examine the behavior of the charge storage mechanism at the electrode-electrolyte interfaces of the fabricated EDLC. At different scan rates, the CV curve is recorded for the PMNG-3 electrolyte as shown in Figure 5.

When the scan rate increased, the curves are observed as changing from a rectangular shape to a leaf-shape, which is caused by the porosity of the carbon electrodes and internal resistance [73]. Based on the CV curves in Figure 5, no peak is observed, which means no oxidation/reduction process occurs in the EDLC using the PMNG-3 system. During the charging process of EDLC, the induced electric field at the positive electrode will attract the anions toward it from the electrolyte, while the negative electrode will attract the cations. The intense electric field from this phenomenon holds the electrons from electrodes and ions from the electrolyte [28]. This reveals that the double-layer charge is generated on the surface of carbon electrodes where the potential energy is stored [74]. The calculated $C_{S}$ values are listed in Table 4 at respective scan rates. Generally, a higher scan rate will cause the specific capacitance to decrease, which will reduce the stored charges on the electrode surface and the energy losses will get higher; thus, the $C_{s}$ values will decrease [75]. 


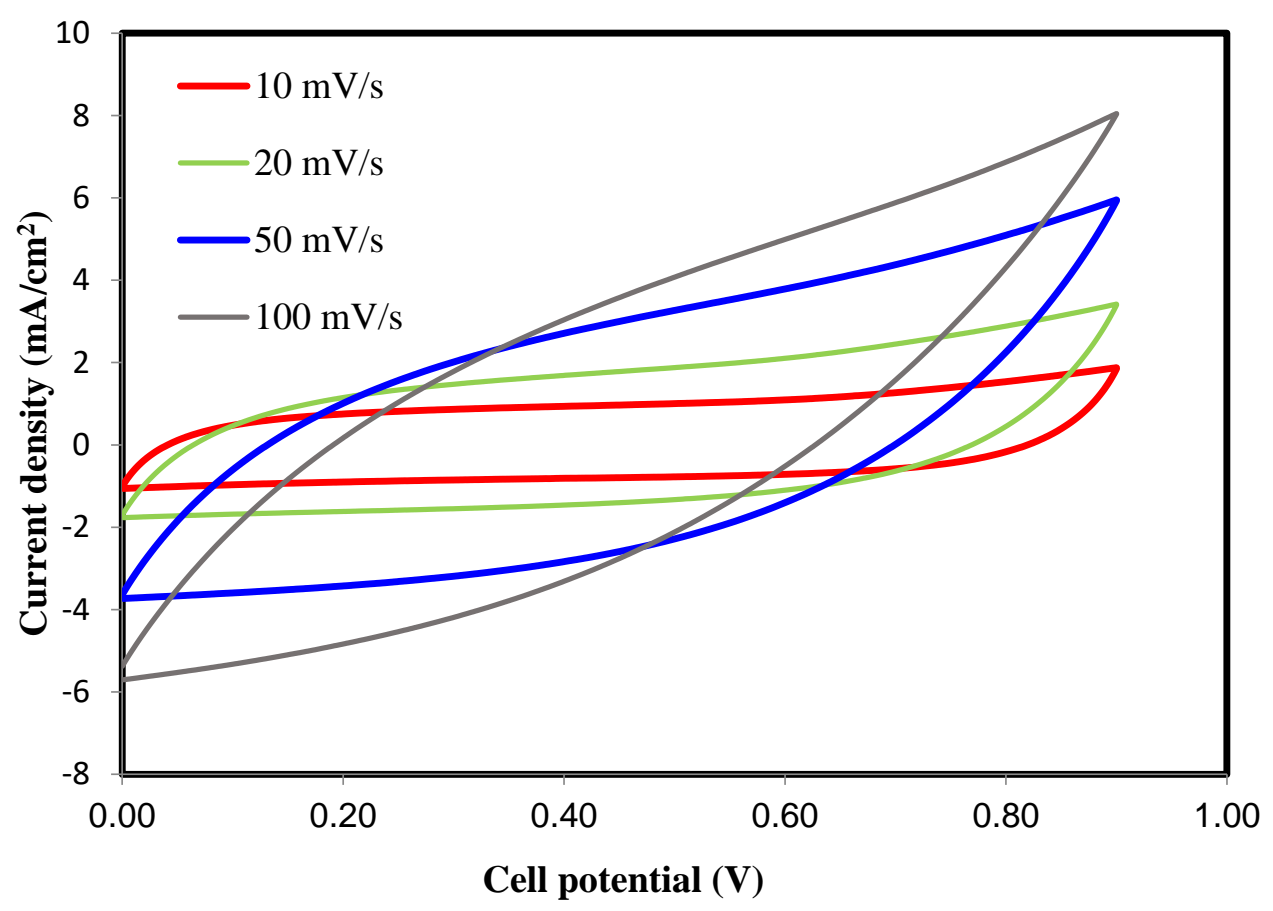

Figure 5. CV curve of the fabricated EDLC using PMNG-3 system.

Table 4. Calculated $C_{s}$ of the EDLC from CV curves.

\begin{tabular}{cc}
\hline Scan Rate $(\mathbf{m V} / \mathbf{s})$ & $\boldsymbol{C}_{\boldsymbol{s}} \mathbf{( F / g )}$ \\
\hline 10 & 102.88 \\
20 & 85.28 \\
50 & 52.58 \\
100 & 28.58 \\
\hline
\end{tabular}

\subsection{Charge-Discharge Study}

The cyclic durability of the EDLC can be determined by using a charge-discharge profile [61]. The profile is used to depict the charging and discharging steps in the EDLC. The charge/discharge curves are shown in Figure 6 for selected cycles.

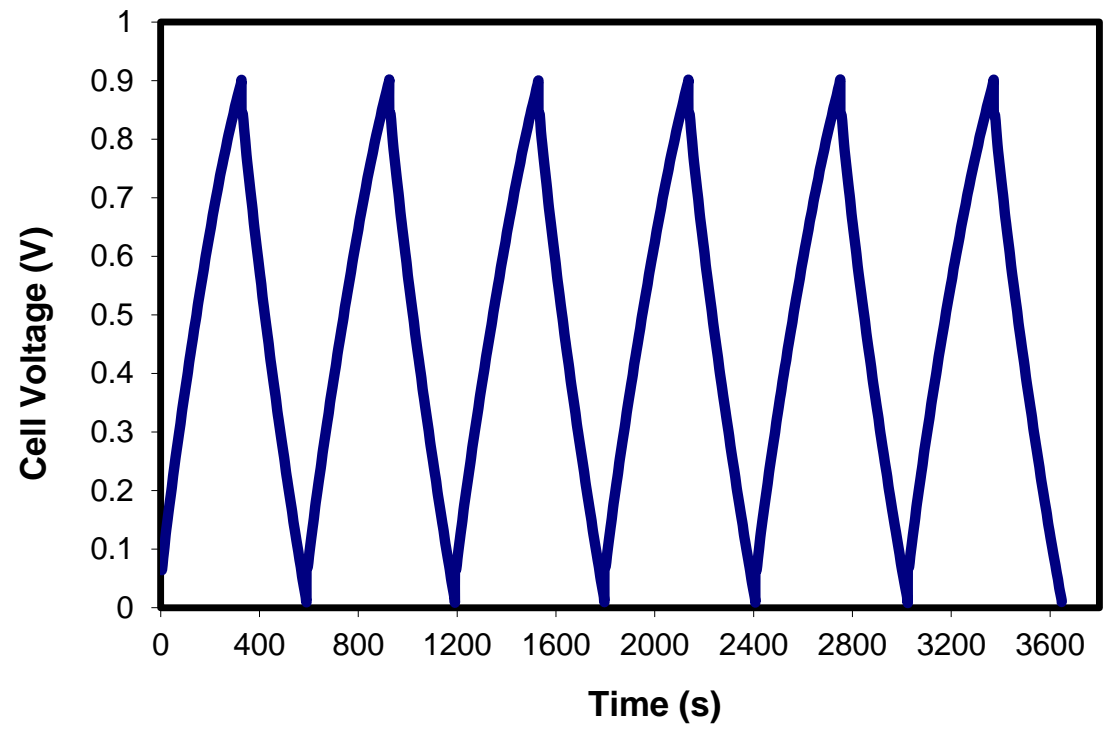

Figure 6. Charge-discharge profiles of EDLC at selected cycles. 
The capacitive behavior of the EDLC is confirmed when the discharge slope is almost linear as shown in the charge-discharge profile [19]. It is noticeable from Figure 7 that the calculated $C_{s}$ at the first cycle is obtained to be $132.7 \mathrm{~F} / \mathrm{g}$ and is slightly higher than $C_{s}$ from $\mathrm{CV}$ curves. According to Yusof et al. [76], these differences are considered to be reliable since both methods prove the characteristics of the capacitor in the EDLC. Next, the $C_{s}$ is increased up to $152.4 \mathrm{~F} / \mathrm{g}$ at the $90^{\text {th }}$ cycle and then gradually decreased to an average value of $124.7 \mathrm{~F} / \mathrm{g}$ until the 200 cycles are completed. The downtrend of the $C_{S}$ value suggests the electrolyte depletion where ion pairs are possibly developed and contribute to the instability of the electrochemical devices [77]. The formation of ion pairs and ion aggregation caused the reduction in mobile charge carriers availability in the transportation between the electrodes. Hence, this will reduce the ion absorption onto the electrodes. A comparable $C_{S}$ value was reported by Muchakayala et al. [75] for the fabricated EDLC by using PVdF-HFP/[PMpyr][NTf $\left.{ }_{2}\right]$ with multiwalled carbon nanotube added activated carbon electrodes, which is at $156.64 \mathrm{~F} / \mathrm{g}$ for 2000 cycles. Therefore, a new electrolyte material as shown in this work can be established in the EDLC with a promising specific capacitance. The authors declared that their electrolyte is a talented candidate for the development of flexible SCs. The specific capacitance values achieved in this work using CV and charge-discharge curves are compared with the previous works as displayed in Table 5.

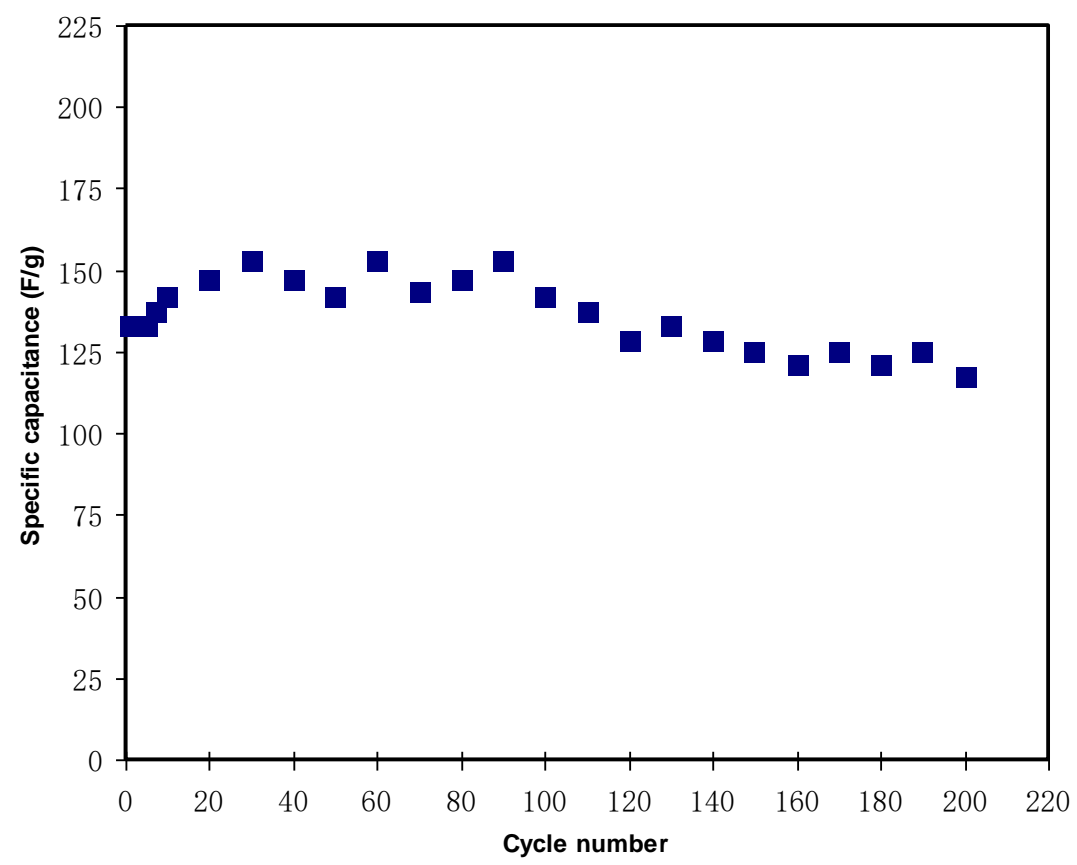

Figure 7. Specific capacitance of the EDLC for 200 cycles.

Table 5. The specific capacitance values of EDLCs using various SPEs.

\begin{tabular}{|c|c|c|c|}
\hline SPEs & $\begin{array}{l}\text { Specific Capacitance } \\
\text { (F/g) Using CV Curve }\end{array}$ & $\begin{array}{c}\text { Specific Capacitance }(\mathrm{F} / \mathrm{g}) \\
\text { Using Charge-Discharge Curve }\end{array}$ & Ref. \\
\hline $\mathrm{MC}: \mathrm{NH}_{4} \mathrm{NO}_{3}: \mathrm{PEG}$ & 25 at $1 \mathrm{mV} \mathrm{s}^{-1}$ & 38 & [78] \\
\hline MC:PS:LiClO 4 :glycerol & 61.58 at $2 \mathrm{mV} \mathrm{s}^{-1}$ & 28.04 & [79] \\
\hline PS:MC: $\mathrm{NH}_{4} \mathrm{NO}_{3}$ :glycerol & 20.48 at $1 \mathrm{mV} \mathrm{s}^{-1}$ & 31 & [80] \\
\hline $\mathrm{CS}: \mathrm{MgCl}_{2}:$ glycerol & 50 at $10 \mathrm{mV} \mathrm{s}^{-1}$ & 117 & [54] \\
\hline CS:MC: $\mathrm{NH}_{4} \mathrm{I}:$ glycerol & 9.97 at $100 \mathrm{mV} \mathrm{s}^{-1}$ & 9.7 & [21] \\
\hline CS: $\mathrm{Mg}\left(\mathrm{CH}_{3} \mathrm{COO}\right)_{2}$ : glycerol & 39.72 at $10 \mathrm{mV} \mathrm{s}^{-1}$ & 78.2 & [54] \\
\hline PVA:MC:NH ${ }_{4}$ SCN:glycerol & 102.88 at $10 \mathrm{mV} \mathrm{s}^{-1}$ & 132.7 & This work \\
\hline
\end{tabular}

Prior to the discharging process beginning as in the charge-discharge profile (Figure 8), the tiny potential drops $\left(V_{d r o p}\right)$ could be due to the internal resistance in the EDLC that is also known as ESR, which can be calculated using Equation (6). Figure 8 displays the obtained ESR values for 200 cycles. 
Based on the ESR plot, it can be observed that at the 1st cycle ESR value is achieved to be $58 \Omega$ and then rises to $171 \Omega$ at the 130th cycle. The results are noticed to remain at a constant reading throughout the 200 cycles.

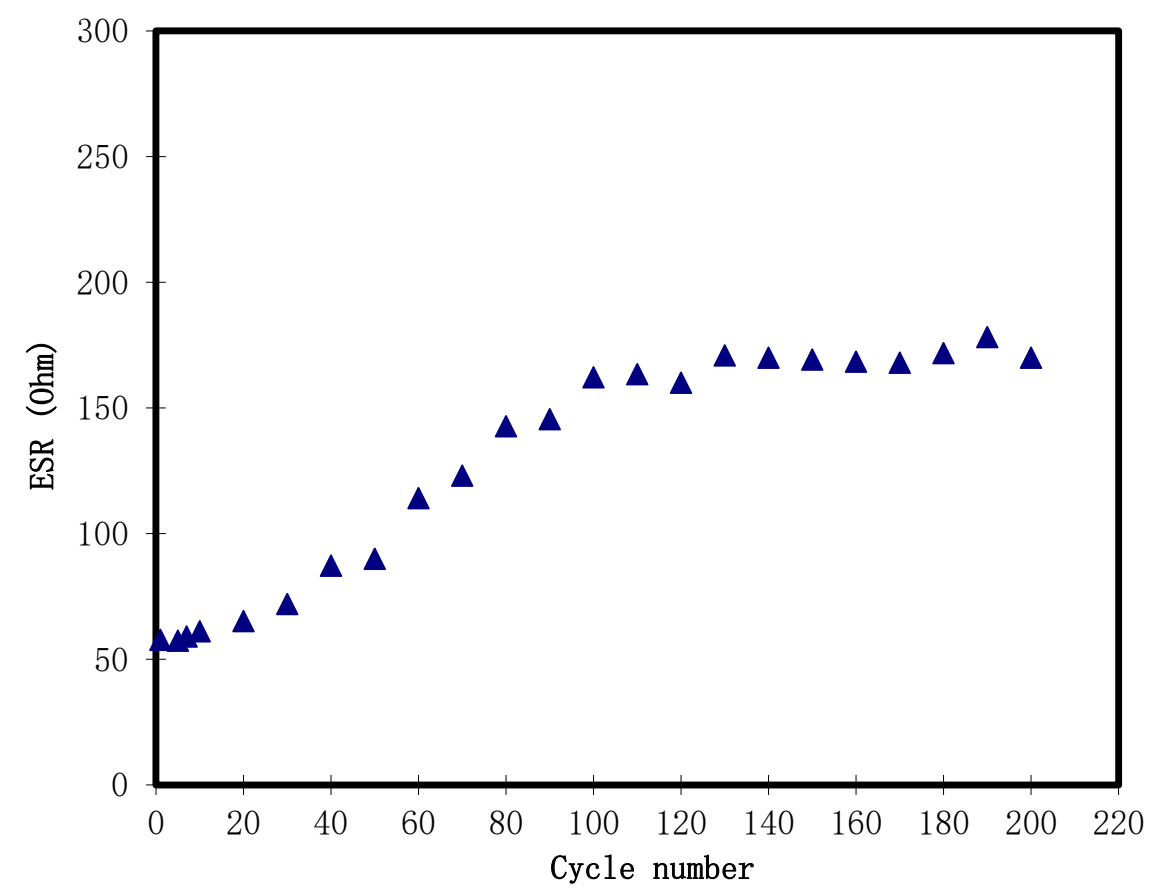

Figure 8. The plot of ESR of the fabricated EDLC for 200 cycles.

It is worth mentioning that the current proton conducting polymer electrolytes based on $\mathrm{NH}_{4} \mathrm{SCN}$ salt exhibits a good DC conductivity of $2.24 \times 10^{-3} \mathrm{~S} \mathrm{~cm}^{-1}$. This value is promising for the energy device applications, and it outweighs many other non-proton conducting-based polymer electrolytes such as lithium perchlorate $\left(\mathrm{LiClO}_{4}\right)$-based electrolytes with a conductivity of $7.34 \times 10^{-4} \mathrm{~S} \mathrm{~cm}^{-1}$ [51], magnesium chloride $\left(\mathrm{MgCl}_{2}\right)$ with a conductivity of $1.03 \times 10^{-3} \mathrm{~S} \mathrm{~cm}^{-1}$ [54], and $2.26 \times 10^{-4}, 4 \times 10^{-5}$, and $1.5 \times 10^{-7} \mathrm{~S} \mathrm{~cm}^{-1}$ for the lithium-based salts $\mathrm{LiClO}_{4}, \mathrm{LiF}_{3} \mathrm{CSO}_{3}$, and $\mathrm{LiBF}_{4}$, respectively [58]. Moreover, the satisfactory electrochemical stability of $2.1 \mathrm{~V}$ in the current work makes the fabricated polymer electrolytes a suitable candidate for the EDLC applications, and opens a gate toward commercializing proton conducting polymer electrolytes. However, in order to meet the industrial level and enhance the EDLC performance, further improvement in the conductivity of polymer electrolytes with establishing good electrode and electrolyte contact are highly demanded.

The small ESR value portrays a good electrode-electrolyte contact and also proves that there is a low resistance for the migration of ions to form electrical double-layer [81]. According to Arof et al. [82], there are a few factors that influenced the existence of the internal resistance; the charging-discharging process of electrolytes, current collector types which are aluminum foils, and the electrolyte-electrode gap. Aziz et al. [19] have reported a similar trend for ESR values in the chitosan/methylcellulose- $\mathrm{NH}_{4} \mathrm{SCN}$ system, where the ESR values are increased at the constant values of $C_{s}$. The recombination of free ions will have occurred from the rapid charging and discharging process, which results in the development of an ion pair, hence the conductivity will decrease.

It is important to determine the Coulombic efficiency $(\eta)$ of the EDLC in order to study its performance and cycling stability. This parameter can be obtained by using Equation (10) [22] and is presented in Figure 9 for 200 cycles.

$$
\eta=\frac{t_{d}}{t_{c}} \times 100
$$

where $t_{c}$ and $t_{d}$ are the charge and discharge times, respectively. The efficiency is found to be $78.9 \%$ at the 1 st cycle and then slightly increases to $89.2 \%$ at 110 th cycle. The efficiency is then observed to remain 
approximately $95.0 \%$ at the 120 th cycle and onwards up to 200 cycles. According to Lim et al. [83], the fabricated EDLC is considered as a likely contact between electrodes and electrolytes when the efficiency is more than $90.0 \%$.

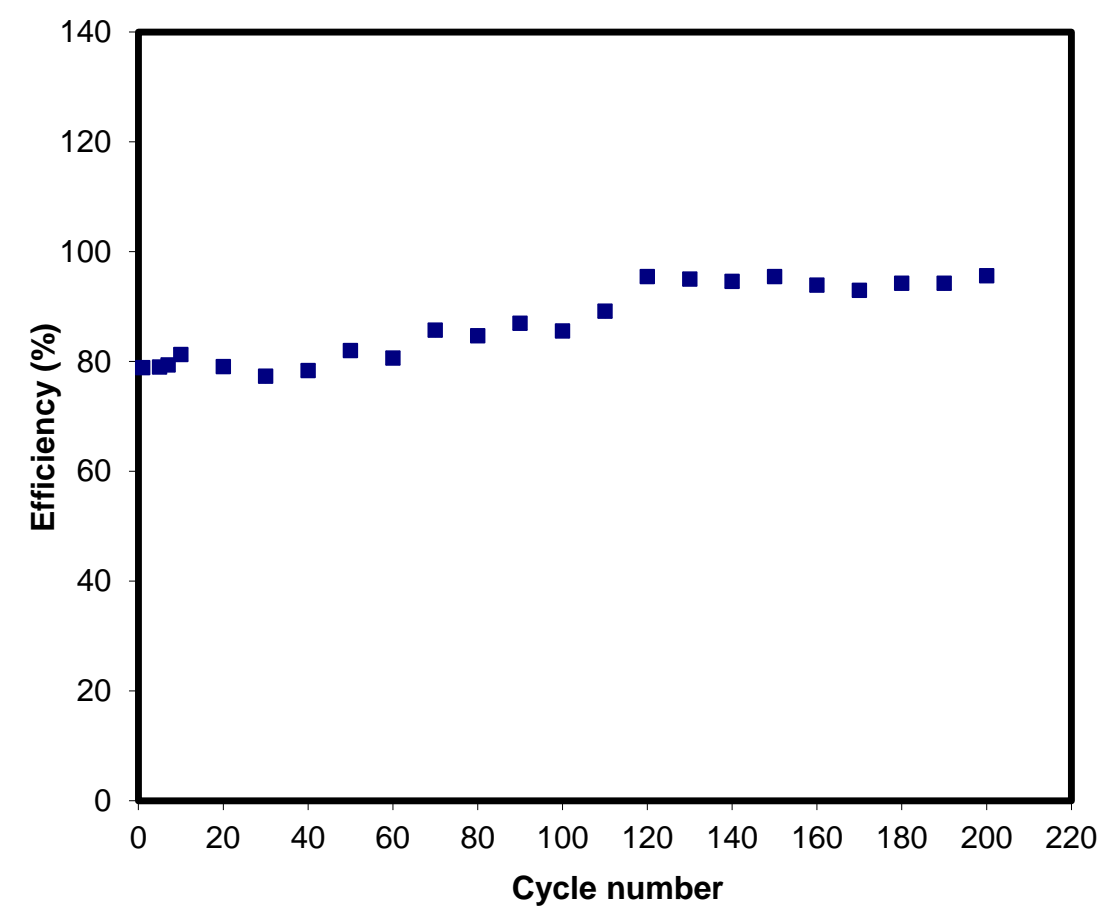

Figure 9. The plot of Coulombic efficiency $(\eta)$ of the fabricated EDLC for 200 cycles.

Other parameters to describe the performance of EDLC are the energy density $(E)$ and as well as the power density $(P)$. These parameters are calculated by using Equations (11) and (12) [20-22]:

$$
\begin{aligned}
& E=\frac{1}{2}\left(C_{s} V^{2}\right) \\
& P=\frac{V^{2}}{4 m(E S R)}
\end{aligned}
$$

Figure 10 illustrates the energy density for 200 cycles. The energy density is found to be at $14.9 \mathrm{Wh} / \mathrm{kg}$ for the 1 st cycle, and it is gradually increased to $17.1 \mathrm{Wh} / \mathrm{kg}$ at the 90 th cycle. The energy density is constant at around $14.0 \mathrm{Wh} / \mathrm{kg}$ at the 100th cycle onwards until the 200th cycle. This trend is in good agreement with the pattern of $C_{s}$ showed in Figure 7. Shukur et al. [64] reported a comparable trend and the authors stated that the amount of energy required for the whole charging-discharging process is similar to the amount required for the migration of charge carriers towards the surface of the electrodes. Furthermore, the power density values are calculated and plotted in Figure 11. It can be observed that the $p$ value at the 1 st cycle is $1444.3 \mathrm{~W} / \mathrm{kg}$. The value is decreased to $572.7 \mathrm{~W} / \mathrm{kg}$ at the $90^{\text {th }}$ cycle and then continuously dropped to $467.6 \mathrm{~W} / \mathrm{kg}$ at the 200th cycle. Besides, the observation on the power density shows that the trend is complementary to Figure 8 for the ESR plot. The occurrence of electrolyte depletion is a result of the increment of internal resistance, hence the fast charging-discharging process will cause the ions to rapidly recombine and therefore the power density will reduce at a high cycle number [84]. 


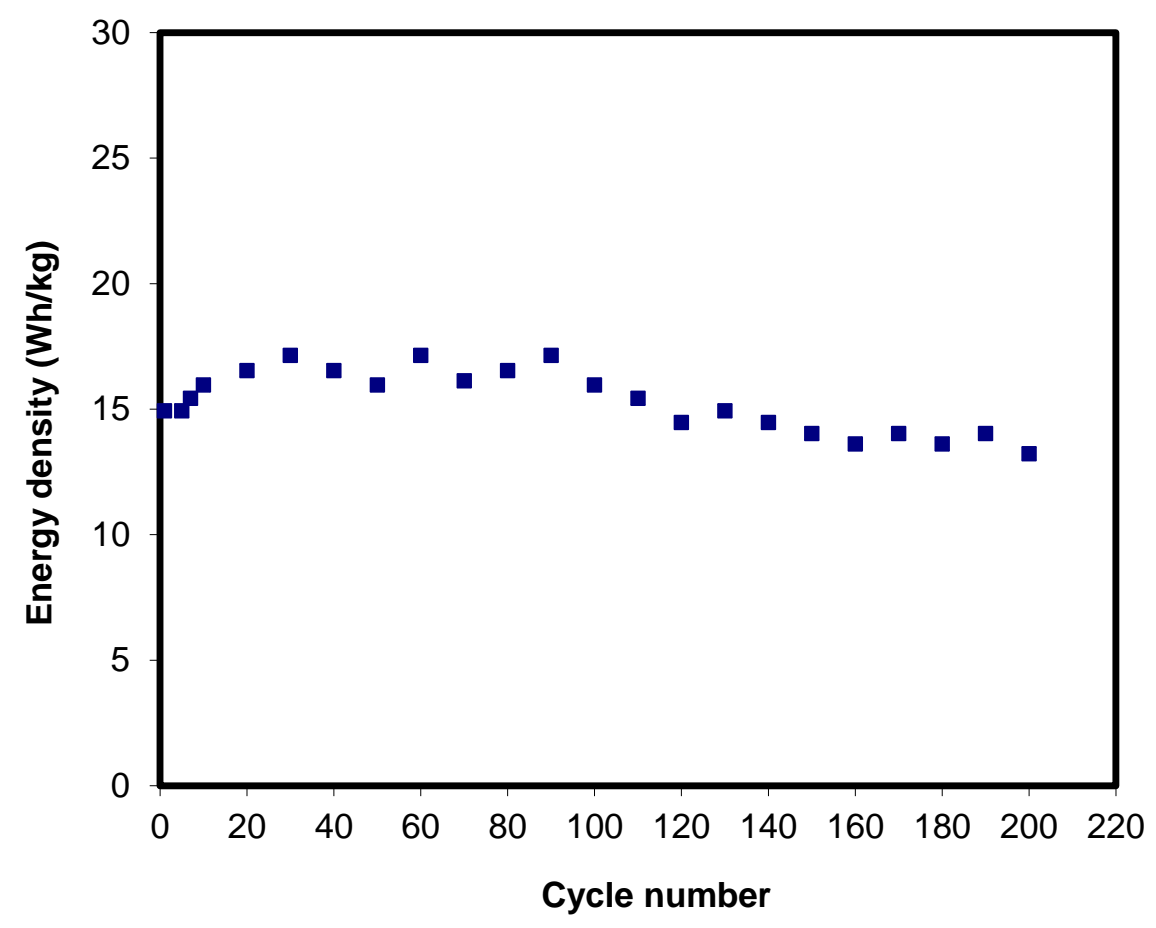

Figure 10. Energy density of the EDLC for 200 cycles.

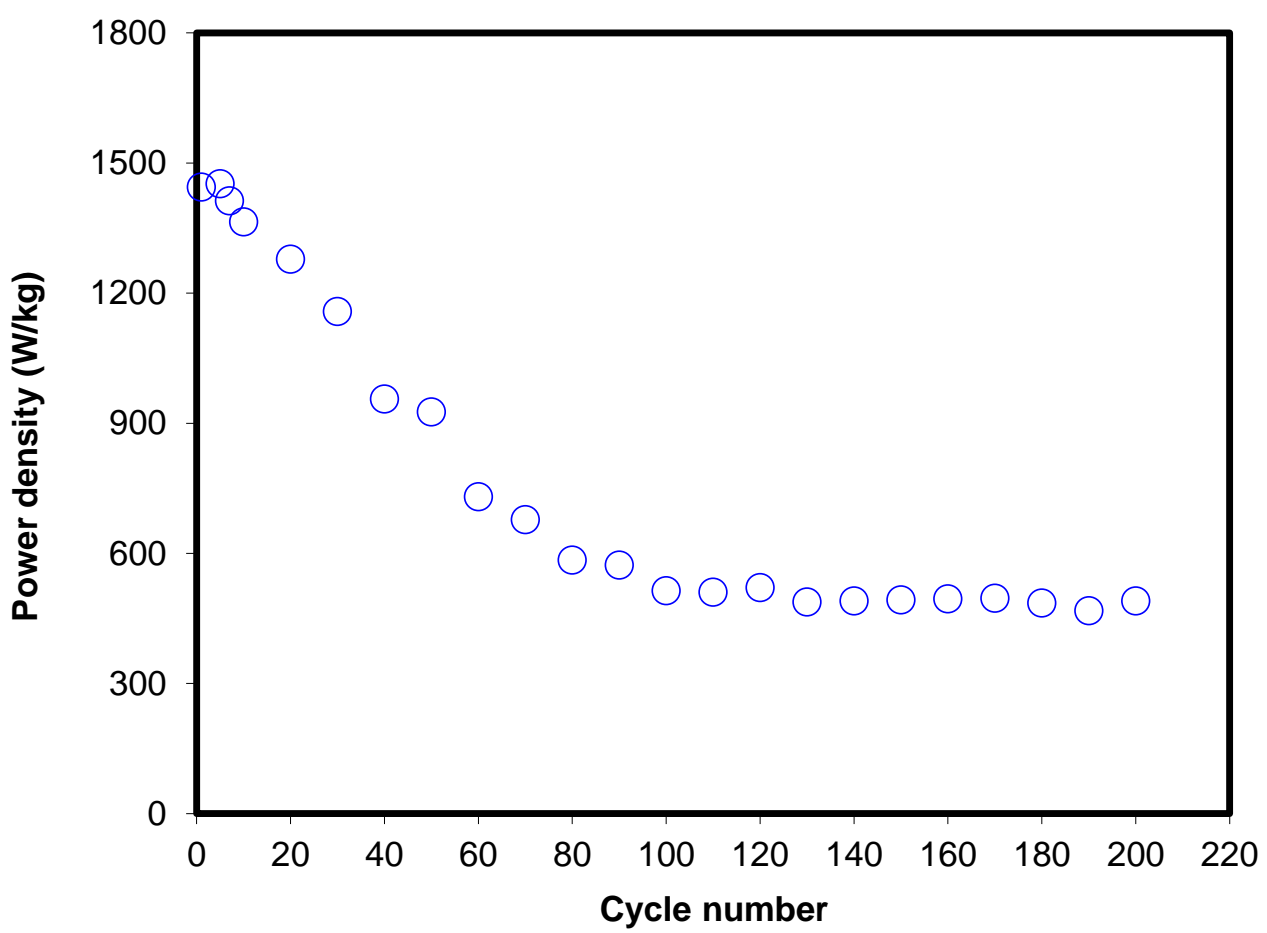

Figure 11. Power density of the EDLC for 200 cycles.

\section{Conclusions}

Solid polymer electrolytes, which were hosted by a PVA/MC- $\mathrm{NH}_{4} \mathrm{SCN}$ polymer blend with a glycerol plasticizer, were successfully prepared by using the solution casting method. XRD technique was displayed in the plasticized electrolyte system with the maximum value of ionic conductivity being the most amorphous system. The ambient temperature DC conductivity of the highest plasticized SPE was found to be $2.903 \times 10^{-3} \mathrm{~S} / \mathrm{cm}$. The TNM analysis confirmed that the ions were the dominant charge carriers in the electrolyte where $t_{\text {ion }}$ and $t_{\text {elec }}$ values were 0.912 and 0.088 , respectively. The LSV 
analysis has shown that the electrochemical stability of the electrolyte is $2.1 \mathrm{~V}$, which is high enough to be applied in EDLC. The CV analysis verified the capacitive characteristics of the EDLC since there were no observable peaks and when the scan rate is increased from $10 \mathrm{mV} / \mathrm{s}$ to $100 \mathrm{mV} / \mathrm{s}$, the $C_{S}$ is reduced from $102.88 \mathrm{~F} / \mathrm{g}$ to $28.58 \mathrm{~F} / \mathrm{g}$. The fabricated EDLC was also stable up to $200 \mathrm{cycles}$, with a steady efficiency at approximately $95.0 \%$. The $C_{s}$ from the charge-discharge analysis was $132.7 \mathrm{~F} / \mathrm{g}$ at the 1st cycle, which is slightly higher that $C_{s}$ from the CV plot. The ESR value was found to be $58 \Omega$ and increased to $171 \Omega$ throughout the cycles. The energy density is approximately constant at $14.0 \mathrm{Wh} / \mathrm{kg}$, while the power density is stabilized at the range of 1444.3 to $467.6 \mathrm{~W} / \mathrm{kg}$ as the EDLC completed the cycles.

Author Contributions: Conceptualization, S.B.A., I.B., E.M.A.D. and M.F.Z.K.; Formal analysis, M.A.B., A.S.F.M.A. and M.H.H.; Funding acquisition, I.B.; Investigation, M.A.B. and M.H.H.; Methodology, S.B.A. and M.A.B.; Project administration, S.B.A., I.B., E.M.A.D., M.M.N. and M.F.Z.K.; Validation, A.S.F.M.A., Y.M.Y. and R.T.A.; Writing—original draft, S.B.A.; Writing—review and editing, I.B., M.A.B., A.S.F.M.A., E.M.A.D., Y.M.Y., R.T.A., M.H.H., M.M.N. and M.F.Z.K. All authors have read and agreed to the published version of the manuscript.

Funding: This research received no external funding.

Acknowledgments: The authors appreciatively acknowledge all the supports for this work by the University of Sulaimani, University of Malaya, Norwegian University of Science and Technology and Komar University of Science and Technology.

Conflicts of Interest: The authors declare no conflict of interest.

\section{References}

1. Sudhakar, Y.N.; Selvakumar, M.; Bhat, D.K. An introduction of Biopolymer Electrolytes. Biopolym. Electrolytes 2018, 1-34. [CrossRef]

2. Zainol, N.H.; Osman, Z.; Othman, L.; Isa, K.B.M. Transport and Morphological Properties of Gel Polymer Electrolytes Containing $\mathrm{Mg}\left(\mathrm{CF}_{3} \mathrm{SO}_{3}\right)_{2}$. Adv. Mater. Res. 2013, 686, 137-144. [CrossRef]

3. Isa, K.B.M. Magnesium ion-based gel polymer electrolytes: Ionic conduction and infrared spectroscopy studies. Int. J. Electrochem. Sci. 2013, 8, 3602-3614.

4. Buraidah, M.H.; Shah, S.; Teo, L.P.; Chowdhury, F.I.; Careem, M.A.; Albinsson, I.; Mellander, B.E.; Arof, A.K. High efficient dye sensitized solar cells using phthaloylchitosan based gel polymer electrolytes. Electrochim. Acta 2017, 245, 846-853. [CrossRef]

5. Riess, I. Polymeric mixed ionic electronic conductors. Solid State Ion. 2000, 136-137, 1119-1130. [CrossRef]

6. Aziz, S.B. Li+ ion conduction mechanism in poly ( $\varepsilon$-caprolactone)-based polymer electrolyte. Iran. Polym. J. 2013, 22, 877-883. [CrossRef]

7. Mustafa, M.S.; Ghareeb, H.O.; Aziz, S.B.; Brza, M.A.; Al-Zangana, S.; Hadi, J.M.; Kadir, M.F.Z. Electrochemical Characteristics of Glycerolized PEO-Based Polymer Electrolytes. Membranes 2020, 10, 116. [CrossRef]

8. Aziz, S.B.; Abidin, Z.H.Z. Electrical and morphological analysis of chitosan: AgTf solid electrolyte. Mater. Chem. Phys. 2014, 144, 280-286. [CrossRef]

9. Hadi, J.M.; Aziz, S.B.; Mustafa, M.S.; Hamsan, M.H.; Abdulwahid, R.T.; Kadir, M.F.Z.; Ghareeb, H.O. Role of nano-capacitor on dielectric constant enhancement in PEO: $\mathrm{NH}_{4} \mathrm{SCN}: \mathrm{xCeO}_{2}$ polymer nano-composites: Electrical and electrochemical properties. J. Mater. Res. Technol. 2020, 9, 9283-9294. [CrossRef]

10. Inagaki, M.; Konno, H.; Tanaike, O. Carbon materials for electrochemical capacitors. J. Power Sources 2010, 195, 7880-7903. [CrossRef]

11. Zhang, D.; Zhang, X.; Chen, Y.; Yu, P.; Wang, C.; Ma, Y. Enhanced capacitance and rate capability of graphene/polypyrrole composite as electrode material for supercapacitors. J. Power Sources 2011, 196, 5990-5996. [CrossRef]

12. Pell, W.G.; Conway, B.E. Peculiarities and requirements of asymmetric capacitor devices based on combination of capacitor and battery-type electrodes. J. Power Sources 2004, 136, 334-345. [CrossRef]

13. Wang, H.; Lin, J.; Shen, Z.X. Polyaniline (PANi) based electrode materials for energy storage and conversion. J. Sci. Adv. Mater. Devices 2016, 1, 225-255. [CrossRef] 
14. Aziz, S.B.; Hamsan, M.H.; Karim, W.O.; Marif, A.S.; Abdulwahid, R.T.; Kadir, M.F.Z.; Brza, M.A. Study of impedance and solid-state double-layer capacitor behavior of proton $(\mathrm{H}+)$-conducting polymer blend electrolyte-based CS:PS polymers. Ionics 2020. [CrossRef]

15. Aziz, S.B.; Hamsan, M.H.; Abdullah, R.M.; Abdulwahid, R.T.; Brza, M.A. Aeyub Shahab Marif, MFZ Kadir, Protonic EDLC cell based on chitosan (CS): Methylcellulose (MC) solid polymer blend electrolytes. Ionics 2020, 26, 1829-1840. [CrossRef]

16. Iro, Z.S.; Subramani, C.; Dash, S.S. A brief review on electrode materials for supercapacitor. Int. J. Electrochem. Sci. 2016, 11, 10628-10643. [CrossRef]

17. Liew, C.W.; Ramesh, S.; Arof, A.K. Investigation of ionic liquid-doped ion conducting polymer electrolytes for carbon-based electric double layer capacitors (EDLCs). Mater. Des. 2016, 92, 829-835. [CrossRef]

18. Irfan, M.; Banu, S.R.; Manjunath, A.; Mahesh, S.S. Effect of dopant on electrical properties of PVA doped $\mathrm{NaF}$ polymer electrolyte films. In AIP Conference Proceedings 1953, 090076 (2018), Proceedings of the 2nd International Conference on Condensed Matter and Applied Physics (ICC 2017), Bikaner, India, 24-25 November 2017; AIP Publishing: New York, NY, USA, 2018.

19. Aziz, S.B.; Hamsan, M.H.; Abdullah, R.M.; Kadir, M.F.Z. A promising polymer blend electrolytes based on chitosan: Methyl cellulose for EDLC application with high specific capacitance and energy density. Molecules 2019, 24, 2503. [CrossRef]

20. Aziz, S.B.; Brza, M.A.; Hamsan, M.H.; Kadir, M.F.Z.; Muzakir, S.K.; Abdulwahid, R.T. Effect of ohmic-drop on electrochemical performance of EDLC fabricated from PVA: Dextran: $\mathrm{NH}_{4} \mathrm{I}$ based polymer blend electrolytes. J. Mater. Res. Technol. 2020, 9, 3734-3745. [CrossRef]

21. Aziz, S.B.; Hamsan, M.H.; Brza, M.A.; Kadir, M.F.Z.; Muzakir, S.K.; Abdulwahid, R.T. Effect of glycerol on EDLC characteristics of chitosan: Methylcellulose polymer blend electrolytes. J. Mater. Res. Technol. 2020, 9 , 8355-8366. [CrossRef]

22. Aziz, S.B.; Hamsan, M.H.; Nofal, M.M.; San, S.; Abdulwahid, R.T.; Raza Saeed, S.R.; Al-Zangana, S. From Cellulose, Shrimp and Crab Shells to Energy Storage EDLC Cells: The Study of Structural and Electrochemical Properties of Proton Conducting Chitosan-Based Biopolymer Blend Electrolytes. Polymers 2020, 12, 1526. [CrossRef]

23. Marf, A.S.; Abdullah, R.M.; Aziz, S.B. Structural, Morphological, Electrical and Electrochemical Properties of PVA:CS-Based Proton-Conducting Polymer Blend Electrolytes. Membranes 2020, 10, 71. [CrossRef] [PubMed]

24. Sundaramahalingam, K.; Muthuvinayagam, M.; Nallamuthu, N.; Vanitha, D.; Vahini, M. Investigations on lithium acetate-doped PVA/PVP solid polymer blend electrolytes. Polym. Bull. 2019, 76, 5577-5602. [CrossRef]

25. Saroj, A.L.; Krishnamoorthi, S.; Singh, R.K. Structural, thermal and electrical transport behaviour of polymer electrolytes based on PVA and imidazolium based ionic liquid. J. Non-Cryst. Solids 2017, 473, 87-95. [CrossRef]

26. Yusof, Y.M.; Illias, H.A.; Kadir, M.F.Z. Incorporation of NH4Br in PVA-chitosan blend-based polymer electrolyte and its effect on the conductivity and other electrical properties. Ionics (Kiel) 2014, 20, 1235-1245. [CrossRef]

27. Buraidah, M.H.; Arof, A.K. Characterization of chitosan/PVA blended electrolyte doped with $\mathrm{NH}_{4} \mathrm{I}$. J. Non-Cryst. Solids 2011, 357, 3261-3266. [CrossRef]

28. Kadir, M.F.Z.; Arof, A.K. Application of PVA-chitosan blend polymer electrolyte membrane in electrical double layer capacitor. Mater. Res. Innov. 2013, 15, S217-S220. [CrossRef]

29. Kadir, M.; Salleh, N.; Hamsan, M.; Aspanut, Z.; Majid, N.; Shukur, M. Biopolymeric electrolyte based on glycerolized methyl cellulose with $\mathrm{NH}_{4} \mathrm{Br}$ as proton source and potential application in EDLC. Ionics (Kiel) 2018, 24, 1651-1662. [CrossRef]

30. Yusof, Y.M.; Kadir, M.F.Z. Electrochemical characterizations and the effect of glycerol in biopolymer electrolytes based on methylcellulose-potato starch blend. Mol. Cryst. Liq. Cryst. 2016, 627, 220-233. [CrossRef]

31. Ndruru, S.T.C.L.; Wahyuningrum, D.; Bundjali, B.; Arcana, I.M. Green synthesis of [EMIm] Ac ionic liquid for plasticizing mc-based biopolymer electrolyte membranes. Bull. Chem. React. Eng. Catal. 2019, 14, 345-357. [CrossRef]

32. Finkenstadt, V.L. Natural polysaccharides as electroactive polymers. Appl. Microbiol. Biotechnol. 2005, 67, 735-745. [CrossRef] 
33. Parameswaran, V.; Nallamuthu, N.; Devendran, P.; Nagarajan, E.R.; Manikandan, A. Electrical conductivity studies on Ammonium bromide incorporated with Zwitterionic polymer blend electrolyte for battery application. Phys. B Condens. Matter. 2017, 515, 89-98. [CrossRef]

34. Bakar, N.Y.A.; Muhamaruesa, N.H.M.; Aniskari, N.A.B.; Isa, M.I.N.M. Electrical Studies of Carboxy Methycellulose-Chitosan Blend Biopolymer Doped Dodecyltrimethyl Ammonium Bromide Solid Electrolytes. Am. J. Appl. Sci. 2015, 12, 40-46. [CrossRef]

35. Gong, S.D.; Huang, Y.; Cao, H.J.; Lin, Y.H.; Li, Y.; Tang, S.H.; Wang, M.S.; Li, X. A green and environment-friendly gel polymer electrolyte with higher performances based on the natural matrix of lignin. J. Power Sources 2016, 307, 624-633. [CrossRef]

36. Yusof, Y.M.; Shukur, M.F.; Illias, H.A.; Kadir, M.F.Z. Conductivity and electrical properties of corn starch-chitosan blend biopolymer electrolyte incorporated with ammonium iodide. Phys. Scr. 2014, 89, 1-10. [CrossRef]

37. Hemalatha, R.; Alagar, M.; Selvasekarapandian, S.; Sundaresan, B.; Moniha, V. Studies of proton conducting polymer electrolyte based on PVA, amino acid proline and NH4SCN. J. Sci. Adv. Mater. Devices 2019, 4, 101-110. [CrossRef]

38. Moniha, V.; Alagar, M.; Selvasekarapandian, S.; Sundaresan, B.; Hemalatha, R.; Boopathi, G. Synthesis and characterization of bio-polymer electrolyte based on iota-carrageenan with ammonium thiocyanate and its applications. J. Solid State Electrochem. 2018, 22, 3209-3223. [CrossRef]

39. Isa, M.I.N.; Noor, N.A.M. Ionic Conduction Mechanism of Solid Biodegradable Polymer Electrolytes Based Carboxymethyl Cellulose Doped Ammonium Thiocyanate. Appl. Mech. Mater. 2015, 719-720, 114-118. [CrossRef]

40. Manavalan, P.; Mathavan, T.; Subramanian, S.; Genova, F.K.M.; Umamaheswari, R. Characterization of proton conducting blend polymer electrolyte using PVA-PAN doped with NH4SCN. In Proceedings of the AIP Conference Proceedings 1731, 070032 (2016), Uttar Pradesh, India, 21-25 December 2015.

41. Aziz, S.B.; Hamsan, M.H.; Kadir, M.F.Z.; Karim, W.O.; Abdullah, R.M. Development of polymer blend electrolyte membranes based on chitosan: Dextran with high ion transport properties for EDLC application. Int. J. Mol. Sci. 2019, 20, 3369. [CrossRef]

42. Liu, P.; Xiangmei, W.; Zhong, L. Miscibility study of chitosan and methylcellulose blends. Adv. Mater. Res. 2013, 750-752, 802-805. [CrossRef]

43. Aziz, S.B.; Brza, M.A.; Mishra, K.; Hamsan, M.H.; Karim, W.O.; Abdullah, R.M.; Kadir, M.F.Z.; Abdulwahid, R.T. Fabrication of high performance energy storage EDLC device from proton conducting methylcellulose: Dextran polymer blend electrolytes. J. Mater. Res. Technol. 2020, 9, 1137-1150. [CrossRef]

44. Nik Aziz, N.A.; Idris, N.K.; Isa, M.I.N. Solid polymer electrolytes based on methylcellulose: FT-IR and ionic conductivity studies. Int. J. Polym. Anal. Charact. 2010, 15, 319-327. [CrossRef]

45. Aziz, S.; Rasheed, M.; Ahmed, H. Synthesis of polymer nanocomposites based on [MethylCellulose](1 $\mathrm{x}):(\mathrm{CuS}) \times(0.02 \mathrm{~m} \leq \mathrm{x} \leq 0.08 \mathrm{~m})$ with desired optical band gaps. Polymers 2017, 9, 194. [CrossRef]

46. Jiang, L.; Yang, T.; Peng, L.; Dan, Y. Acrylamide modified poly(vinyl alcohol): Crystalline and enhanced water solubility. RSC Adv. 2015, 5, 86598-86605. [CrossRef]

47. Aziz, S.B.; Hassan, A.Q.; Mohammed, S.J.; Karim, W.O.; Kadir, M.F.Z.; Tajuddin, H.A.; Chan, N.N.M.Y. Structural and optical characteristics of PVA: C-Dot composites: Tuning the absorption of ultra violet (UV) region. Nanomaterials 2019, 9, 216. [CrossRef]

48. Aziz, S.B. Modifying poly(vinyl alcohol) (PVA) from insulator to small-bandgap polymer: A novel approach for organic solar cells and optoelectronic devices. J. Electron. Mater. 2016, 45, 736-745. [CrossRef]

49. Aziz, S.B. Role of dielectric constant on ion transport: Reformulated Arrhenius equation. Adv. Mater. Sci. Eng. 2016, 2016, 2527013. [CrossRef]

50. Wan, Y.; Creber, K.A.M.; Peppley, B.; Bui, V.T. Synthesis, characterization and ionic conductive properties of phosphorylated chitosan membranes. Macromol. Chem. Phys. 2003, 204, 850-858. [CrossRef]

51. Aziz, S.B.; Hamsan, M.H.; Brza, M.A.; Kadir, M.F.Z.; Abdulwahid, R.T.; Ghareeb, H.O.; Woo, H.J. Fabrication of energy storage EDLC device based on CS:PEO polymer blend electrolytes with high Li+ ion transference number. Results Phys. 2019, 15, 102584. [CrossRef]

52. Aziz, S.B.; Brza, M.A.; Hamsan, H.M.; Kadir, M.F.Z.; Abdulwahid, R.T. Electrochemical characteristics of solid state double-layer capacitor constructed from proton conducting chitosan-based polymer blend electrolytes. Polym. Bull. 2020. [CrossRef] 
53. Reddy, M.J.; Chu, P.P. Ion pair formation and its effect in PEO:Mg solid polymer electrolyte system. J. Power Sources 2002, 109, 340-346. [CrossRef]

54. Hamsan, M.H.; Aziz, S.B.; Nofal, M.M.; Brza, M.A.; Abdulwahid, R.T.; Hadi, J.M.; Kadir, M.F.Z. Characteristics of EDLC device fabricated from plasticized chitosan: $\mathrm{MgCl}_{2}$ based polymer electrolyte. J. Mater. Res. Technol. 2020, 9, 10635-10646. [CrossRef]

55. Aziz, S.B.; Abdullah, R.M.; Kadir, M.F.Z.; Ahmed, H.M. Non suitability of silver ion conducting polymer electrolytes based on chitosan mediated by barium titanate $\left(\mathrm{BaTiO}_{3}\right)$ for electrochemical device applications. Electrochim. Acta 2019, 296, 494-507. [CrossRef]

56. Nasef, M.M.; Saidi, H.; Dahlan, K.Z.M. Preparation of composite polymer electrolytes by electron beam-induced grafting: Proton- and lithium ion-conducting membranes. Nucl. Instrum. Methods Phys. Res. Sect. B Beam Interact. Mater. At. 2007, 265, 168-172. [CrossRef]

57. Samsudin, A.S.; Khairul, W.M.; Isa, M.I.N. Characterization on the potential of carboxy methylcellulose for application as proton conducting biopolymer electrolytes. J. Non-Cryst. Solids 2012, 358, 1104-1112. [CrossRef]

58. Fonseca, C.P.; Cavalcante, F.; Amaral, F.A.; Souza, C.A.Z.; Neves, S. Thermal and conduction properties of a PCL-biodegradable gel polymer electrolyte with $\mathrm{LiClO}_{4}, \mathrm{LiF}_{3} \mathrm{CSO}_{3}$, and $\mathrm{LiBF}_{4}$ salts. Int. J. Electrochem. Sci. 2007, 2, 52-63.

59. Misenan, M.; Khiar, A. Conductivity, Dielectric And Modulus Studies of Methylcellulose-NH $\mathrm{NF}_{4}$ Polymer Electrolyte. Eurasian J. Biol. Chem. Sci. 2018, 1, 59-62.

60. Aziz, S.B.; Abidin, Z.H.Z.; Arof, A.K. Influence of silver ion reduction on electrical modulus parameters of solid polymer electrolyte based on chitosansilver triflate electrolyte membrane. Express Polym. Lett. 2010, 4, 300-310. [CrossRef]

61. Liew, C.W.; Ramesh, S.; Arof, A.K. Good prospect of ionic liquid based-poly(vinylalcohol) polymer electrolytes for supercapacitors with excellent electrical, electrochemical and thermal properties. Int. J. Hydrogen Energy 2014, 39, 2952-2963. [CrossRef]

62. Selvasekarapandian, S.; Baskaran, R.; Hema, M. Complex AC impedance, transference number and vibrational spectroscopy studies of proton conducting PVAc-NH4SCN polymer electrolytes. Phys. B Condens. Matter 2005, 357, 412-419. [CrossRef]

63. Mohapatra, S.R.; Thakur, A.K.; Choudhary, R.N.P. Effect of nanoscopic confinement on improvement in ion conduction and stability properties of an intercalated polymer nanocomposite electrolyte for energy storage applications. J. Power Sources 2009, 191, 601-613. [CrossRef]

64. Shukur, M.F.; Ithnin, R.; Kadir, M.F.Z. Electrical characterization of corn starch-LiOAc electrolytes and application in electrochemical double layer capacitor. Electrochim. Acta 2014, 136, 204-216. [CrossRef]

65. Shukur, M.F.; Ithnin, R.; Kadir, M.F.Z. Ionic conductivity and dielectric properties of potato starch-magnesium acetate biopolymer electrolytes: The effect of glycerol and 1-butyl-3-methylimidazolium chloride. Ionics (Kiel) 2016, 22, 1113-1123. [CrossRef]

66. Shukur, M.F.; Ithnin, R.; Kadir, M.F.Z. Protonic Transport Analysis of Starch-Chitosan Blend Based Electrolytes and Application in Electrochemical Device. Mol. Cryst. Liq. Cryst. 2014, 603, 52-65. [CrossRef]

67. Chai, M.N.; Isa, M.I.N. Novel Proton Conducting Solid Bio-polymer Electrolytes Based on Carboxymethyl Cellulose Doped with Oleic Acid and Plasticized with Glycerol. Sci. Rep. 2016, 6, 1-7. [CrossRef]

68. Rani, M.S.A.; Ahmad, A.; Mohamed, N.S. Influence of nano-sized fumed silica on physicochemical and electrochemical properties of cellulose derivatives-ionic liquid biopolymer electrolytes. Ionics (Kiel) 2018, 24, 807-814. [CrossRef]

69. Shukur, M.F.; Hamsan, M.H.; Kadir, M.F.Z. Investigation of plasticized ionic conductor based on chitosan and ammonium bromide for EDLC application. Mater. Today Proc. 2019, 17, 490-498. [CrossRef]

70. Francis, K.A.; Liew, C.W.; Ramesh, S.; Ramesh, K.; Ramesh, S. Ionic liquid enhanced magnesium-based polymer electrolytes for electrical double-layer capacitors. Ionics (Kiel) 2016, 22, 919-925. [CrossRef]

71. Sampathkumar, L.; Selvin, P.C.; Selvasekarapandian, S.; Perumal, P.; Chitra, R.; Muthukrishnan, M. Synthesis and characterization of biopolymer electrolyte based on tamarind seed polysaccharide, lithium perchlorate and ethylene carbonate for electrochemical applications. Ionics (Kiel) 2019, 25, 1067-1082. [CrossRef]

72. Shuhaimi, N.E.A.; Alias, N.A.; Majid, S.R.; Arof, A.K. Electrical Double Layer Capacitor With Proton Conducting K-Carrageenan-Chitosan Electrolytes. Funct. Mater. Lett. 2009, 1, 195-201. [CrossRef] 
73. Bandaranayake, C.M.; Weerasinghe, W.A.D.S.S.; Vidanapathirana, K.P.; Perera, K.S. A Cyclic Voltammetry study of a gel polymer electrolyte based redox-capacitor. Sri Lankan J. Phys. 2016, 16, 19. [CrossRef]

74. Fattah, N.F.A.; Ng, H.M.; Mahipal, Y.K.; Numan, A.; Ramesh, S.; Ramesh, K. An approach to solid-state electrical double layer capacitors fabricated with graphene oxide-doped, ionic liquid-based solid copolymer electrolytes. Materials (Basel) 2016, 9, 450. [CrossRef]

75. Muchakayala, R.; Song, S.; Wang, J.; Fan, Y.; Bengeppagari, M.; Chen, J.; Tan, M. Development and supercapacitor application of ionic liquid-incorporated gel polymer electrolyte films. J. Ind. Eng. Chem. 2018, 59, 79-89. [CrossRef]

76. Yusof, Y.M.; Majid, N.A.; Kasmani, R.M.; Illias, H.A.; Kadir, M.F.Z. The Effect of Plasticization on Conductivity and Other Properties of Starch/Chitosan Blend Biopolymer Electrolyte Incorporated with Ammonium Iodide. Mol. Cryst. Liq. Cryst. 2014, 603, 73-88. [CrossRef]

77. Liew, C.W.; Ramesh, S.; Arof, A.K. Characterization of ionic liquid added poly(vinyl alcohol)-based proton conducting polymer electrolytes and electrochemical studies on the supercapacitors. Int. J. Hydrogen Energy 2015, 40, 852-862. [CrossRef]

78. Shuhaimi, N.E.A.; Teo, L.P.; Woo, H.J.; Majid, S.R.; Arof, A.K. Electrical double-layer capacitors with plasticized polymer electrolyte based on methyl cellulose. Polym. Bull. 2012, 69, 807-826. [CrossRef]

79. Yusof, Y.M.; Shukur, M.F.; Hamsan, M.H.; Jumbri, K.; Kadir, M.F.Z. Plasticized solid polymer electrolyte based on natural polymer blend incorporated with lithium perchlorate for electrical double-layer capacitor fabrication. Ionics 2019. [CrossRef]

80. Hamsan, M.H.; Shukur, M.F.; Kadir, M.F.Z. $\mathrm{NH}_{4} \mathrm{NO}_{3}$ as charge carrier contributor in glycerolized potato starch-methyl cellulose blend-based polymer electrolyte and the application in electrochemical double-layer capacitor. Ionics 2017, 23, 3429-3453. [CrossRef]

81. Arof, A.K.; Kufian, M.Z.; Syukur, M.F.; Aziz, M.F.; Abdelrahman, A.E.; Majid, S.R. Electrical double layer capacitor using poly(methyl methacrylate)-C 4BO8Li gel polymer electrolyte and carbonaceous material from shells of mata kucing (Dimocarpus longan) fruit. Electrochim. Acta 2012, 74, 39-45. [CrossRef]

82. Asmara, S.N.; Kufian, M.Z.; Majid, S.R.; Arof, A.K. Preparation and characterization of magnesium ion gel polymer electrolytes for application in electrical double layer capacitors. Electrochim. Acta 2011, 57, 91-97. [CrossRef]

83. Lim, C.S.; Teoh, K.H.; Liew, C.W.; Ramesh, S. Capacitive behavior studies on electrical double layer capacitor using poly (vinyl alcohol)-lithium perchlorate based polymer electrolyte incorporated with $\mathrm{TiO}_{2}$. Mater. Chem. Phys. 2014, 143, 661-667. [CrossRef]

84. Zhong, C.; Deng, Y.; Hu, W.; Qiao, J.; Zhang, L.; Zhang, J. A review of electrolyte materials and compositions for electrochemical supercapacitors. Chem. Soc. Rev. 2015, 44, 7484-7539. [CrossRef]

Publisher's Note: MDPI stays neutral with regard to jurisdictional claims in published maps and institutional affiliations.

(C) 2020 by the authors. Licensee MDPI, Basel, Switzerland. This article is an open access article distributed under the terms and conditions of the Creative Commons Attribution (CC BY) license (http://creativecommons.org/licenses/by/4.0/). 